DOI: 10.2478/ausfm-2021-0003

\title{
Screens of the Picturesque: Aesthetics, Technology, Economy
}

\author{
György Fogarasi \\ University of Szeged (Hungary) \\ E-mail: fogarasi@hung.u-szeged.hu
}

\begin{abstract}
The 18th-century notion of the picturesque is somewhat lesser known as compared to the more celebrated categories of the beautiful and the sublime, even though it may not only help us critically reflect upon modern perceptions of the landscape, but it may also provide us a unique way to link the field of aesthetic speculation with questions of technology and economy. The article will focus on two of the major theoreticians of the picturesque (William Gilpin and Uvedale Price) and will examine their ideas in relation to Edmund Burke's aesthetics on the one hand, and contemporary tendencies in landscape gardening (as represented by Lancelot "Capability" Brown and Humphry Repton) on the other. Such an investigation may shed light on the multiple shifts in the perception of nature and the sense of naturalness during the long 18th century, as well as on the pictorial and theatrical aspects of landscape design. But examples of the Claude glass, the ha-ha, and Humphry Repton's Red Books may also indicate the role of technological innovations and economic interests, and thereby the relevancy of the very discourse of the picturesque to more modern or even postmodern artistic, cultural, and medial developments.
\end{abstract}

Keywords: picturesque, English garden, aesthetics, technology, economy.

The 18th-century notion of the picturesque is somewhat lesser known as compared to the more frequently discussed aesthetic categories of the beautiful and the sublime. A closer look at its emergence may not only help us critically reflect upon modern perceptions of the landscape, but it may also provide a unique way to link the field of aesthetic speculation with questions of technology and economy. One way to do so is to trace the ways in which, well before the emergence of cinema, or even of photography, the picturesque is intimately linked to practices of screening. While today, picturesque spectacles seem to flood cinematic, television or computer screens, in a more archaic sense of the term, "screens" were part and parcel of the development of landscape gardens and the evolving discourse on 
the picturesque throughout the long 18th century, at least in two respects. From a technological point of view, the notion of the picturesque applied to landscaping implies a logic of framing, one based upon the blotting out of unwanted visual elements by lines of trees used as theatrical "screens," while from an economic perspective, the picturesque is closely intertwined with a practice of idealization, in which landscape gardens have been used as "screen" memories (Deckerinnerungen, in the Freudian sense), with a function to conceal the trauma of forced enclosures. Looking into two of the major theories of the picturesque (by William Gilpin and Uvedale Price), as well as their relation to contemporary practices in landscape gardening (as developed by Lancelot "Capability" Brown and Humphry Repton), will serve as an occasion to spell out these linkages between aesthetics, technology, and economy, and the multiple "screens" of the picturesque.

At the beginning of the 18th century, the English term "picturesque" was still understood in a much broader sense as compared to the meaning it came to bear later on. In its initial sense, it could refer to any of the favoured objects or themes of painting. Alexander Pope, for instance, applied it with reference to the historical and mythological scenes of the Iliad. At the point when he speaks of the vigour or liveliness (enargeia) of Homer's expressions, he refers to the natural environment of these scenes as "the most picturesque imaginable" (Pope 1996, 513).

The narrower contours of the concept were drawn by William Gilpin, who recounted his ramblings in England, Wales and Scotland in travelogues illustrated with his own sketches or water colour paintings. In contrast to the Grand Tour, which targeted the ancient relics of the Mediterranean, Gilpin's travel writing contributed to the growing popularity of the homeland tour. Besides, the descriptions he gave both of landscapes and of emotions and thoughts elicited by viewing them turned loco-descriptive writing into a major mode of aesthetic speculation. Gilpin's speculative wanderings had a great impact on subsequent generations, and the romantics' emotional attachment to the Wye valley or the Lake District was considerably informed by such readings. The following description of the landscape surrounding the ruins of Tintern Abbey on the bank of the Wye would later echo in William Wordsworth's romantic descriptions of the Wye valley: "the abbey, intended for meditation, is hid in the sequestered vale. [...] It occupies a gentle eminence in the middle of a circular valley, beautifully screened on all sides by woody hills; through which the river winds its course; and the hills, closing on its entrance, and on its exit, leave no room for inclement blasts to enter. A more pleasing retreat could not easily be found. The woods, and glades intermixed; the winding of the river; the variety of the ground; the splendid ruin, contrasted with 
the objects of nature; and the elegant line formed by the summits of the hills, which include the whole; make all together a very enchanting piece of scenery. Every thing around breathes an air so calm, and tranquil; so sequestered from the commerce of life, that it is easy to conceive, a man of warm imagination, in monkish times, might have been allured by such a scene to become an inhabitant of it" (Gilpin 1782, 31-32, emphasis mine, Gy. F.). According to this passage, the environment of the abbey is first and foremost a "scene" or "scenery," and that is how it has a power to seduce monks or wanderers to visit its location, to stay, linger, and meditate. For us, however, it is Gilpin himself who produces a framed spectacle out of this site by describing it as something circularly enclosed and hidden "in the sequestered vale," "sequestered from the commerce of life." "Screened" by the surrounding hills, the valley attains its beauty due to the vision-blocking geographical formations that encapsulate it, as the hills screen out any visually disturbing effects from the background, just like theatrical screens that are supposed to block the spectator's gaze from seeing the backstage. That is how Tintern Abbey and its situation are produced as a scenery, as a site to be seen, a demarcated natural spectacle with easily discernible contours. That is how the abbey's location is actually turned into a landscape, which is not just a sight but also a soundscape as far as screening does not only blot out unwanted visual elements but also any noise that might disrupt the tranquillity of the place. The potentially negative sentiment of isolation is counterbalanced by a notion of homeliness, the image of the spot as a "retreat" for any shelter-seeking "inhabitant." Apart from providing a verbal description, Gilpin at this point also offers his readers a watercolour illustration, shown within an oval frame and representing the secluded spot of the ruins. While he appears merely to copy the circular formation of the valley through the verbal and pictorial arts of description, he in fact actively participates in the phantasmatic production of the landscape as a framed scene with clear outlines.

Gilpin first addressed the question of the picturesque in his 1768 book An Essay upon Prints, where he treated it as a kind of natural beauty, associating the term with another adjective, the "romantic." In the glossary of his book, "picturesque beauty" appears as "that peculiar kind of beauty, which is agreeable in a picture" (Gilpin 1768, x). What he implied was that natural spectacles that can only evoke pleasure when represented in painting can in fact be pleasurable even upon direct viewing when viewed as if they were depicted in a picture.

To view nature as a painting or picture was not simply an intellectual feat for Gilpin and his contemporaries. There was a particular device that was supposed to assist travellers in their aestheticizing efforts. This was the Claude glass, a mid-size, 
slightly dimmed and convex mirror, set in a square or oval frame and covered by a lid for the purposes of protection (and also perhaps to serve as a support when the mirror was placed on the ground). It was so named after the 17th-century French landscape painter Claude Lorrain, because it provided large angles and dimmed hues so characteristic of his pictures. A contemporary of Gilpin, Thomas West referred to it as a "landscape mirror" in the introduction to his Guide to the Lakes in Cumberland, Westmorland, and Lancashire (1778), and suggested that, next to a telescope, travellers should also take along such a glass in order to more fully enjoy the beauties of nature (West 1778, 15). The Claude glass served as a technological enhancement of the aesthetic experience of nature in several respects. Firstly, due to its convex surface, it provided a large angle view and thus made it possible for spectators to take in relatively close spectacles or vast objects. Secondly, its dimmed glass reduced the brightness of the sun, which made the clouds or waves more clearly discernible, also making the bushes, trees, or shady areas in the foreground (or the figures standing in their proximity) gloomy - a feature again reminiscent of Lorrain's paintings. And thirdly, it actually framed a selected part of nature, turning the place into a vision, the site into a sight, that is, into a landscape. No wonder it was widely used as a tool in the service of the aesthetic enjoyment of nature. (And no wonder, it is still in use, albeit in a somewhat different form and size, and under a different name, as reflectoscope, in various touristic locations, most notably at the Desert View vista point on the Southern rim of the Grand Canyon.) ${ }^{1}$ Since, however, as West himself admitted, "the person using it ought always to turn his back to the object that he views" (West 1778, 15), travellers chasing the picturesque beauties of nature (stumbling around with a Claude glass in their hands, amazed by the spectacles of nature, and perhaps also by their own reflected image) soon became objects of public ridicule - funny prototypes of the selfie-maker, as we would perceive them today.

Gilpin was well-acquainted with this device and recognized its potentials early on, as is clear from the 1789 account of his 1776 journey to Scotland. But he still had reservations concerning its usefulness or necessity. For him, it is the human mind that makes us capable of viewing landscapes as if they were pictures, so there is no need for any specific technical aid $(1789,1,124)$. The same principle of the

1 The Desert View watchtower was designed by May Colter in 1932 according to Ancestral Puebloan architectural style. Apart from the tower, visitors may also enjoy the view of the landscape from the adjoining terrace, by looking into 45-degree inclined dimmed mirrors built into the surrounding stone barrier, which provide a somewhat darkened but relatively sharp and vivid picture of the canyon. In the hall beneath the terrace, large windows frame the landscape as so many paintings, and beside them, huge reflectoscopes offer dimmed pictures of the same views. 
"as if" is highlighted in Gilpin's later work of 1792, Three Essays, a book which attempts to clarify the picturesque in three consecutive studies: the first one on picturesque beauty, the second one on picturesque travel, and the third one on the principles of sketching landscape. In this book, the adjective "picturesque" is attached at times no longer to this or that external object, but to the spectator himor herself. The adjective is tellingly transferred from the object to the gaze at the moment when Gilpin speaks of the shaping power of the "picturesque eye" (1792, 24). According to his argument, it is primarily due to the activity of the picturesque eye that picturesqueness is ultimately not confined to nature, but can be found also in human products or artefacts, especially if they are ruinous $(1792,45-46)$.

The reason why ruins came to provide the main examples for the picturesque needs further explanation. As opposed to Edmund Burke's aesthetic theory, according to which beauty is attached to the qualities of smoothness and gradual change, Gilpin associates picturesque "beauty" precisely to features that Burke linked to the category of the sublime: fragmentation or roughness. Whether we speak of the picturesqueness of nature or art, fragmentation is in both cases pleasurable because, according to the principle of the "as if," the spectator views the spectacle as a painting. The picturesque eye frames, as it were, and thus artistically beautifies the real. Gilpin brings the example of mountainous areas full of rocks, crags, sharp ridges, and sudden obtrusions. For an artistic counterpart of such natural sights, he mentions shabby or half-collapsed buildings. According to his provocative claim, a classicist edifice acquires its picturesque "form" not by the "chisel" but by the "mallet:" "A piece of Palladian architecture may be elegant in the last degree. The proportion of its parts - the propriety of its ornaments - and the symmetry of the whole may be highly pleasing. But if we introduce it in a picture, it immediately becomes a formal object, and ceases to please. Should we wish to give it picturesque beauty, we must use the mallet instead of the chisel; we must beat down one half of it, deface the other, and throw the mutilated members around in heaps. In short, from a smooth building we must turn it into a rough ruin. No painter, who had the choice of the two objects, would hesitate a moment" $(1792,7-8)$. With the emergence of the cult of ruined landscapes and buildings we are witnessing the emergence of a practice of designing or building spontaneous-looking vegetations and artificial ruins.

Gilpin's book of 1792 played an important role in the developing speculation on the picturesque, and was one of the main reasons why a debate concerning the practices of landscape design broke out in the last decade of the century. The debate was erupted by Uvedale Price's book, An Essay on the Picturesque (1794). Price's polemic was by no means a lonesome gesture. Just a few months earlier, his close 
friend and intellectual companion Richard Payne Knight voiced a similar critique in his didactic poem, The Landscape, a piece dedicated to Price himself.

Price's book had two targets to hit. On the one hand, it contested Gilpin's theory, while on the other, it unleashed an attack on the landscape planning practices of the so-called "improvers" (William Kent, Lancelot Brown, and Humphry Repton). As for the former, Price was generally impressed by Gilpin's description of the picturesque (Price 1794, 34-35), he even tried perfecting or completing it. Yet, in opposition to Gilpin's conception, he lay strong emphasis on the necessity to more clearly distinguish the picturesque both from the beautiful and the sublime, and thus to add an important appendix to Burkean aesthetics. Just as Gilpin, Price himself associated the picturesque with irregularity, brokenness, roughness, or sudden change $(1794,43-45)$, but since Burke had placed these attributes outside the beautiful, within the realm of the sublime, Price saw Gilpin's notion of "picturesque beauty" as a gross confusion of the picturesque with the beautiful $(1794,42)$. For Price, the picturesque can also be terrible, ugly, or even deformed. On the other hand, picturesqueness just as much differs from sublimity, as far as terror is by no means a necessary component in the picturesque experience. Price finally concludes that the picturesque neither relaxes, nor stretches the fibres. Instead, it "corrects the langour of beauty, or the horror of sublimity" $(1794,86)$.

For Price, the emphasis falls on feelings of mutability, or "decayed grandeur" (1794, 71). According to him, time is what "converts a beautiful object into a picturesque one" (1794, 47-48). Although his examples contain many of the classical occurrences of the sublime (from rushing mountain torrents to thundering waterfalls, or wild animals like a stubborn ass, a formidable lion, or various birds of prey), more significant are examples that indicate the emerging cult of ruins, or, in some ways, even the extension of that cult. Beside the ruins of Greek temples or Gothic cathedrals there begin to appear other buildings such as old mills, cottages, huts, shanties, barns, and stables - all of them in distressful shape, decaying, on the way to collapse, and overgrown with ivy. Among Price's series of examples, one also finds certain plants (old oak trees, struck by thunderstorm and lightening), as well as certain types of humans (cottagers, beggars, gypsies, elderly women and men, and other shabby looking creatures). Thus, according to Price's description, the cult of ruins did not only involve architectural remains, it also encompassed fading vegetations or vegetating humans. ${ }^{2}$ As part of this cult, the wealthiest

2 While the cult of ruins was to elevate decomposition and death through artistic stylization, it also contributed to the emergence of an aesthetics of disgust. Ever since Joseph Addison's mention, in his Pleasures of the Imagination, of a painted "dunghill" as a potential source of pleasure, disgusting images appeared more and more frequently in aesthetic speculations. 
landowners even hired hermits to sit and meditate by the ruins. With the addition of plants and buildings, the two-dimensional pictorial admiration of the landscape gained a dimension of depth, but with the employment of paid hermits a further dimension of time was added. As a result, the aesthetic enjoyment of the landscape came to a completion in the four-dimensional complexity of theatrical art, and the picturesque was indeed "staged" for viewing.

The other target of Price's book, attacked with even greater vehemence, was the gardening and landscape planning practice of the "improvers." Their major representative was Lancelot "Capability" Brown, the inventor of the long-lasting idea of the "English garden," or, as Price called him, the "great legislator of our national taste" $(1794,188)$. Brown designed more than 250 parks for his wealthy customers throughout England, parks like Stowe, Petworth, Croome Court, Chatsworth, or Ashridge Estate. In consequence of the enclosures that took place from the 15th through the 19th centuries, huge territories of fertile ground went into private possession. A new class of landowners was formed and with them emerged a market which helped Brown make landscape improvement into a new industrial branch. His nickname "Capability" was itself a result of his marketing slogan, for he tried to convince his future customers about the necessity to improve their estates (an investment that could even involve the displacement of small villages or hills, or the creation of lakes) by underlining the extraordinary "capabilities" of the property in question. Brown himself was of course part of a larger process of transformation: he continued the work of William Kent, painter and gardener, who himself followed the footsteps of former royal gardener Charles Bridgeman. They tried to replace French style "formal gardens" with irregular, asymmetrical formations, to create the impression of spontaneous growth. At the basis of these improvements it is not at all difficult to recognize some of the characteristics that Burke would later subsume under the rubric of the beautiful: the smoothness of surfaces, their gentle alteration, the gradual, hardly perceptible change that evokes pure pleasure.

Brown added a whole array of technical innovations. Next to the winding walkways, there emerged "false rivers," which were lakes in reality, but their

Cottages and cottagers were perceived as prime examples (Macarthur 2007, 115). In A Dialogue on the Distinct Characters of the Picturesque and the Beautiful (included in a later edition of his Essay on the Picturesque), Price himself elaborated on the possibility to find entertainment in such images. He brought the example of Dutch pictures, among them Rembrandt's painting of the carcass of an ox (Slaughtered $O x, 1655$ ), arguing that one could perceive such pictures "not only without disgust, but with a degree of pleasure," although the subject is mean and even offensive (Price 1842, 525). What is more, even "the real carcass of an ox" will "lose part of its disgusting appearance" when viewed through a Claude glass (a mirror "often made use of for viewing scenery" (Price 1842, 528). 
serpentine shape made it practically impossible for any viewer to spot the whole water surface or the whole bank, so they could indeed look as if they had been tiny rivers. Here and there Brown placed clumps of trees upon the hilltops and made the environment of the buildings pleasingly varied by exotic plants (like cedar trees, evergreen oaks, or plane trees). He favoured a green lawn running from the main building up to the riverbank or the wood, and was strongly against bushes, with a preference for full transparency. Brown shared Pope's conviction that "all gardening is landscape painting" (quoted by Hunt 1992, 106), and the main principle guiding his improvements was that of spectatorship. Much to Knight's regret, Brown "banish'd the thickets," and was convinced that "every thing which indicated decay should be removed" (Knight 1794, 17, 52). The sunken wall (the so-called "ha-ha"), already used by Kent to keep away live stock (sheep or deer) from the close proximity of the central mansion, itself served the purposes of unobstructed viewing. Brown several times used it in the neighbourhood of the main building. In the distance, on the other hand, he planted lines of trees or a strip of wood to function as a screen whose major role was not only to physically isolate the garden from its wider surroundings, but to prevent the eye from seeing unwanted elements in the distance that would have spoiled the painterly impression. Thus, these screens were installed to form an apt background for the newly created formations in the foreground. They were not only supposed to screen out disturbing elements, but also to actually frame the landscape. The effect was enhanced by some ancient or oriental looking building, rotund, shrine, stone bridge, or by an artificial ruin that domesticated mutability by stylistic elevation.

Following Brown's death in 1783, one of his disciples, Humphry Repton became the main promoter of the tradition of landscape design. Repton, who actually coined the expression "landscape gardening" and was also the major target of Knight's poem and Price's essay in 1794 among the contemporaries, became famous primarily for his professionalism in business. He presented his recommendations for improvement to his potential customers in "Red Books," in the form of watercolour illustrations, which were supposed to amaze landowners by showing them, with the help of hinged pictures, a before-and-after view of the particular segments of the estate that he was proposing to reshape. Customers could then order his services on the basis of seductive images and the landscape clearly became an object of purchase in the form of a picturesque spectacle. Land improvement soon turned into a status symbol, the fashionable way of "gratifying purse-proud vanity," as Knight put it $(1794,11)$.

With the 18th-century emergence and intensification of homeland tourism, the owners of landscape gardens gradually developed a "heritage industry" (De 
Bolla 2003, 136), partly in the service of their own "purse-proud vanity," partly in order to forge a more solid national identity. They offered visitors guided walks around their mansions, inviting them to spend a few days immersing in the views of plants, animals, buildings, as well as busy working gardeners and servants around them. Spontaneous as these may have seemed, such walks were carefully planned to provide a pleasurable everyday image both of natural processes and human activity. But the growing invasion of tourists in the countryside also elicited an increasing uneasiness among contemporaries, a resentment often packaged in sarcasm or mockery. Dorothy Wordsworth bitterly referred to the multitude of visitors as "prospect-hunters and 'picturesque travellers"” $(1874,97)$, while her brother William, whose view of the Lake District has been largely shaped by the descriptions of Thomas Gray and Thomas West (by their different views, for instance, about the ideal prospect of Grasmere), expressed serious reservations in his own Guide through the District of the Lakes concerning the doctrine of the picturesque (W. Wordsworth 1835, 102). ${ }^{3}$ Later on, some have produced critical gestures in a more literary vein. William Combe's narrative poem The Tour of Doctor Syntax in Search of the Picturesque (1812) parodied Gilpin as a prospect-hunter (to send him hunting for consolation and for a wife in two successive volumes). Jane Austen's Mansfield Park (1814) or Thomas Love Peacock's Headlong Hall (1816) might also be seen as instances of literary mockery that target the zeal of picturesque travellers or gardeners, as well as the controversial economy surrounding their practices. ${ }^{4}$

Price had nothing against the picturesque quality of landscapes, nor did he deny the necessity for land improvers to study landscape painting. He also agreed that landscapes should not fall prey to violent human intervention, since he believed that gardeners should act in a way which creates the impression of the spontaneous self-formation of nature, so that walking spectators, immersed in the enjoyment of such views, would experience the free proliferation of vegetative life. The difference between him and the improvers rather lay in precisely what kind of pictures, what

3 On the other hand, in a partial polemic with Klopstock, Wordsworth used the term in a linguistic context when he argued that the German language is "more picturesque," than most others, because "it depictures images better" due to its ability to unite more images simultaneously in a single word by the prolific use of prefixes. He brought the examples of the verbs reissen and schmelzen, with potential prefixes like ver-, zer-, ent- etc. (W. Wordsworth 1876, 3: 412-413).

4 The British vogue of prospect-hunting would later find its professionalized large-scale equivalent in the New World, in the US national park system (with Yellowstone, Grand Canyon, and Yosemite as its flagships). Vista points in these parks have been offering natural spectacles as a kind of "found art," turning landscapes into "outdoor museums," based upon a newly evolving market of the "picturesque commodity" (Byerly 1996, 55 and 59). Due to a recently implemented ecological paradigm, today the same parks are attempting to provide visitors scientific insights into "nature’s laboratory” (Byerly 1996, 64). 
specimens of landscape painting they kept in mind, and what image of nature they cherished as a model for the "naturalness" of landscapes. The improvers (Kent, Brown and Repton) promoted an image of nature which seemed more and more artificial in the perception of critics like Price, whose notion of the picturesque ideal was much closer to the emergent romantic idea of a raw and untamed nature. In his view, although Kent and his followers aimed "to banish formality, and to restore nature," the result was just the opposite: "formality still remains; the character of that formality alone is changed" (Price 1796, 247). Thus, although the English gardens were supposed to replace the formal gardens of the French, all they did was to substitute one type of formality for another: "they may have substituted other narrow prejudices and absurdities in the room of those which they had banished" (Price 1796, 248). And since Price's own idea of an untouched, raw or rugged wilderness may have just as well become subject to suspicion, by the end of the 18th century, more and more critics have doubted whether any landscape could be called "natural," and many came to share William Marshall's insight that "Nature scarcely knows the thing mankind call a landscape" $(1785,604)$.

That the English garden, so "romantic" in the public mind, was in some ways a mere idealization even for some of the romantics could also be formulated from a different perspective - if one considers the particular events that created the infrastructural and economic basis of these gardens, that is, if one takes heed of the several waves of violent enclosures and all the trauma they meant for four centuries. The English garden is ultimately nothing but a gentle, tranquilizing cultural veil, an idyllic memory in the British social imaginary that is supposed to screen out all the violence and robbery taking place at its birth. Seen from the angle of historic brutality, the English garden has been functioning as the most effective "screen memory" possible (Freud 1962), whose lasting popularity and role in the forging of a national character erases the trauma of its own emergence, namely, the fact that it deprived whole communities of their common grounds (pastures and plough fields), thus depriving them of their fundamental resources for living. No wonder the enclosures became propelling forces in the development of modern capitalist economy and also became classical examples for "original accumulation" (ursprüngliche Akkumulation), if I may refer to Karl Marx, who in the related chapter of the first volume of Capital did not hesitate to call these violent moves sheer "terrorism" (Marx 1992, 895). Not to speak of the fact that the maintenance of these newly created private gardens was financed largely by the profits coming from the colonies (colonization being the other major mode of original accumulation for Marx). 
Starting as early as the 13th century, the intensity of enclosing common lands first reached its peak during the 15th and 16th centuries, with the "piecemeal" enclosure of mostly open arable fields (Williams 1975, 96). General or so-called "parliamentary" enclosure, on the other hand, appeared later as a more sophisticated form of the expropriation of common lands. ${ }^{5}$ As John Macarthur explains: "commons were areas of land held by a parish over which rights were held by members of the parish on differing bases, but they were usually connected with ownership or tenancy of other land or cottages. The parish administered shared rights of grazing and cultivation on commons. While large enclosed pieces of land owned by a single interest had always been a form of land tenure, the end of the eighteenth century saw a vast increase in the scale of enclosure" (Macarthur 2007, 117). Parliamentary enclosure took place in two waves during the 18th and 19th centuries, with the first wave between 1750 and 1780 still concentrating on open arable lands and reaching a total amount of 4.4 million acres, while the second wave between 1793 and 1815 was focusing mostly on common "waste" grounds and reaching 2.3 million acres - the two waves covering altogether nearly one-quarter of the area of England (Oles 2015, 75). All this was processed by way of nearly 4000 Acts brought by Parliament (Williams 1975, 96). The usual procedure of parliamentary enclosure began with an informal negotiation among the landowners of a given parish, at least the four-fifths of whom would then draft a petition for a bill of enclosure to be introduced in Parliament. Upon the passage of the bill an enclosure commissioner was appointed to carry out the rest of the transformation, that is, to have the parish surveyed, convince potential opposition, and finally produce an "enclosure award" map performing the reallotment of the parish, a document which projected new boundaries upon the land (often fundamentally reconfiguring former parcels and roads), against which no contesting or appealing was in place (Oles 2015, 76-77). That is what Marx called the "parliamentary form of the robbery" (Marx 1992, 885), for he saw in it a legal procedure which produced "the wealth of the nation" (indeed "the wealth of the few") out of "the poverty of the people" ("the poverty of the great majority”) (Marx 1992, 873, 886). He approvingly cited Richard Price, the most published 18th-century defender of commons, for whom England was becoming a kingdom "of only gentry and beggars, or of grandees and slaves" (Marx 1992, 829, cf. Neeson 1996, 25). In Price's view, engrossing was in fact "erecting private benefit on public calamity" (quoted in Neeson 1996, 26). Accordingly, for Marx, the enclosure of the commons, even in its parliamentary form, appeared as just another

$5 \quad$ For the different meanings of enclosure, as well as the difference between piecemeal and general enclosure, see Yelling 1977, 5-6. 
evidence for the fact that original accumulation was intimately intertwined with diverse forms of violence: with "conquest, enslavement, robbery, murder, in short, force [Gewalt]" (Marx 1992, 874).

But, as some readers have pointed out, the Marxian critique of the "anything but idyllic" methods of original accumulation itself implies the phantasm of a previous idyll, the myth of a "pre-enclosure 'rural democracy"” (Williams 1975, 102), a picture which itself needs to be critically examined. As Raymond Williams argued, the Marxian myth of an organic or natural society before capitalism and urban industrialism promotes the idyllic picture "of independent and honourable men, living in a working rural democracy, who were coldly and 'legally' destroyed by the new enclosing order" $(1975,100)$. The Marxian description of this process neglected several other factors (the growth of population, the changing birth and death rates, or the increase in agricultural production) which had just as much contributed to the formation of the impoverished working class of the new industrial towns (Williams 1975, 98). Enclosure was "a factor within this complex of change, but not a single isolated cause" $(1975,104)$. So, for Williams, the difference is rather "a matter of degree" $(1975,106)$, implying both an intensification of expropriation, of violence already present in earlier decades and centuries, and a continuation of certain practices of negotiation and persuasion, of protocols that gave the process its legal framework.

Parliamentary enclosure was still "a form of legalized seizure enacted by representatives of the beneficiary class" (Williams 98). With a compensation that was "unjust and overcomplicated" (Macarthur 2007, 117), villagers were deprived of their right of cultivating common arable fields, as well as of grazing cattle or gathering fuel on nearby pastures and wastes. As Williams concludes, "what was drastically reduced, by enclosures, was just such a breathing-space, a marginal dayto-day independence, for many thousands of people" $(1975,107)$. As a result, "the economic system of landlord, tenant and labourer, which had been extending its hold since the sixteenth century, was now in explicit and assertive control" (1975, 107). The series of general enclosure acts enabled a new and highly productive "rational" agriculture, but a price was to be paid. While the enclosure of common land may have rationalized or modernized agriculture, it also increased the dependence of agricultural workers on largely seasonal wages, and the resulting cyclical unemployment produced a more "tractable work-force" not only for improved agriculture but also for factories (Macarthur 2007, 118). As a result, a large number of villagers flooded the cities and became the propelling torque of an evolving industrial economy. 
As far as the concomitant theories of the picturesque have contributed to the nourishment of the idyllic image that was supposed to obliterate this violent past, they have also participated in the screening out of a history that is laden with agony and harm. Such a traumatic history is what lurks uncannily behind the 18th-century picturesque landscape and its theoretical underpinnings in aesthetic discourse.

\section{References}

Byerly, Alison. 1996. The Uses of Landscape: The Picturesque Aesthetic and the National Park System. In The Ecocriticism Reader: Landmarks in Literary Ecology, eds. Cheryll Glotfelty and Harold Fromm, 52-68. Athens and London: The University of Georgia Press.

De Bolla, Peter. 2003. The Education of the Eye: Painting, Landscape, and Architecture in Eighteenth-Century Britain. Stanford: Stanford University Press. Freud, Sigmund. 1962 [1899]. Screen Memories. In The Standard Edition of the Complete Psychological Works of Sigmund Freud, vol. 3, 301-322. London: The Hogarth Press.

Gilpin, William. 1768. An Essay upon Prints: Containing Remarks upon the Principles of Picturesque Beauty; the Different Kinds of Prints; and the Characters of the Most Noted Masters: Illustrated by Criticisms upon Particular Pieces: to which are Added, Some Cautions that May be Useful in Collecting Prints. London: G. Scott.

Gilpin, William. 1789. Observations, Relative Chiefly to Picturesque Beauty, Made in the Year 1776, on Several Parts of Great Britain; Particularly the High-Lands of Scotland, vol. 1. London: Printed for R. Blamire.

Gilpin, William. 1792. Three Essays: on Picturesque Beauty; on Picturesque Travel; and on Sketching Landscape: to which is added a poem, on Landscape Painting. London: Printed for R. Blamire.

Hunt, John Dixon. 1992. Gardens and the Picturesque: Studies in the History of Landscape Architecture. Cambridge, Mass.: M.I.T. Press.

Knight, Richard Payne. 1794. The Landscape, a Didactic Poem. London: W. Bulmer. Macarthur, John. 2007. The Picturesque: Architecture, Disgust and Other Irregularities. London: Routledge.

Marshall, William. 1785. Planting and Ornamental Gardening. London: J. Dodsley. Marx, Karl. 1992 [1976]. Capital: A Critique of Political Economy, vol. 1. London: Penguin. 
Neeson, J. M. 1996 [1993]. Commoners: Common Right, Enclosure and Social Change in England, 1700-1820. Cambridge: Cambridge University Press.

Oles, Thomas. 2015. Walls: Enclosure and Ethics in the Modern Landscape. Chicago and London: The University of Chicago Press.

Pope, Alexander, transl. 1996. The Iliad of Homer. Vol. 1. London: Penguin.

Price, Uvedale. 1794. Enlarged edition: 1796. An Essay on the Picturesque, as Compared with the Sublime and the Beautiful; and, on the Use of Studying Pictures, for the Purpose of Improving Real Landscape. London: Printed for J. Robson.

Price, Uvedale. 1842. A Dialogue on the Distinct Characters of the Picturesque and the Beautiful. In Sir Uvedale Price On the Picturesque: with an Essay on the Origin of Taste, and Much Original Matter by Sir Thomas Dick Lauder, Bart, 505-555. Edinburgh: Caldwell, Lloyd, and Co. - London: Wm. S. Orr and Co.

West, Thomas. 1778. A Guide to the Lakes in Cumberland, Westmorland, and Lancashire. London: Richardson and Urquhart and Pennington.

Williams, Raymond. 1975 [1973]. Enclosures, Commons and Communities. In The Country and the City, 96-107. Oxford: Oxford University Press.

Wordsworth, Dorothy. 1874 [1803]. Recollections of a Tour in Scotland. New York: G. P. Putnam's Sons.

Wordsworth, William. 1835. A Guide through the District of the Lakes. Kendal: Hudson and Nicholson.

Wordsworth, William. 1876. Klopstock: Notes of His Conversation. In The Prose Works of William Wordsworth Vol. III. Critical and Ethical, ed. Alexander B. Grosart, 405-423. London: Edward Moxon, Son, and Co.

Yelling, J. A. 1977. Common Field and Enclosure in England, 1450-1850. London: Macmillan. 